\title{
PEMILIHAN MODEL KEAMANAN LAUT INDONESIA DENGAN FUZZY AHP DAN FUZZY TOPSIS
}

\author{
Hozairi $^{1)}$, Buhari' ${ }^{2}$, Heru Lumaksono $^{3)}$, Marcus Tukan ${ }^{4)}$, Syariful Alim ${ }^{5)}$ \\ 1), 2) Program Studi Teknik Informatika, Fakultas Teknik, Universitas Islam Madura \\ 3) Program Studi Teknik Bangunan Kapal, Politeknik Perkapalan Negeri Surabaya \\ 4) Program Studi Teknik Industri, Fakultas Teknik, Universitas Pattimura \\ 5) Program Studi Teknik Informatika, Fakultas Teknik, Universitas Bhayangkara Surabaya \\ Jl. Raya PP. Miftahul Ulum Bettet,Universitas Islam Madura, Pamekasan, Madura \\ Email:마.hozairi@gmail.com ${ }^{I)}, \underline{\text { buhari.nahrawi@gmail.com }}{ }^{2}$, heruppns@gmail.com $^{3)}$
}

\begin{abstract}
Abstrak
Indonesia merupakan Negara kepulauan yang memiliki luas lautan yang luas sebesar dua pertiga dari luas wilayah keseluruhan. Oleh karena itu, Indonesia memiliki tingkat kerawanan yang tinggi di antaranya illegal fishing, illegal logging, illegal mining, illegal migrant, human trafficking dan penyelundupan. Sehingga Indonesia memerlukan model pengamanan laut yang mampu mengoptimalkan resource yang ada. Proses pemilihan model pengamanan laut tidaklah mudah karena harus mempertimbangkan banyak kriteria sehingga keputusan yang diambil tidak salah, maka diperlukan suatu Sistem Pendukung Keputusan (SPK) yang dapat memperhitungkan segala kriteria yang mendukung pengambilan keputusan dalam menentukan model pengamanan laut yang cocok untuk Indonesia. Metode yang digunakan dalam pengambilan keputusan adalah Fuzzy AHP (Analytical Hierarcy Process) dan Fuzzy TOPSIS (Technique For Order Preference by Similarity to Ideal Solution). Hasil penilaian prioritas model pengamanan laut diperoleh sebagai berikut: [1] Single Agency Multy Task $=0.404$, [2] Multy Agency Single Task $=0.295$, [3] Single Agency Single Task $=0.228$ dan [4] Multy Agency Multy Task $=0.073$. Oleh karena itu, penelitian ini merekomendasikan model pengamanan laut yang paling cocok dengan kondisi Indonesia saat ini adalah "Single Agency Multy Task" dengan bobot prioritas 0.404. Melalui sistem "Single Agency Multy Tasks" persoalan pengawasan dan pengamanan laut dapat ditingkatkan karena model Single Agency Multy Task menghendaki adanya satu lembaga atau badan bersifat tunggal, integratif dalam pelaksanaan pengamanan laut Indonesia.
\end{abstract}

Kata kunci : Fuzzy AHP, Fuzzy TOPSIS, Keamanan Laut

\begin{abstract}
Indonesia is an archipelagic country that has a vast ocean area of two-thirds of total area. Therefore, Indonesia has a high level of vulnerability such as illegal fishing, illegal logging, illegal mining, illegal migrants, human trafficking and smuggling. So Indonesia needs a marine safety model that is able to optimize existing resources. The process of selecting a marine security model is not easy because it must consider many criteria so the decision taken is not wrong, it is necessary a Decision Support System (DSS) can take into any criteria that support the decision making in determining a marine security model suitable for Indonesia. The methods used are Fuzzy AHP (Analytical Hierarcy Process) and Fuzzy TOPSIS (Technique For Order Preference by Similarity to Ideal Solution). The priority assessment of marine safety model are [1] Single Agency Multy Task $=0.404$, [2] Single Agency Single Task $=0.295$, [3] Single Agency Single Task $=0.228$ and [4] Multy Agency Multy Task $=0.073$. Therefore, this research recommends that the most suitable marine security model with Indonesia condition is "Single Agency Multy Task" with priority weight of 0.404. Through the Single Agency Multy Tasks system, marine surveillance and security issues can be improved because Single Agency Multy Task model requires a single, integrative body or entity in implementation of Indonesian marine security.
\end{abstract}

Keywords : Fuzzy AHP, Fuzzy TOPSIS, Marine Security 


\section{Pendahuluan}

Negara kesatuan Republik Indonesia (NKRI) adalah negara kepulauan yang terdiri dari 17.504 pulau dan memiliki pantai sepanjang 81.290 kilometer. Sebagai negara kepulauan dengan $80 \%$ wilayah laut dan $20 \%$ wilayah darat, ancaman terhadap kedaulatan dan wilayah Indonesia berada di laut. Prosentase ancaman ini menjadi semakin tinggi karena posisi geografi Indonesia berada dalam lalu lintas perdagangan dunia. Setiap hari ratusan kapal, baik kapal dagang maupun militer melintas di perairan Indonesia melalui Sea Lanes of Communication (SLOC) serta Sea Lines of Oil Trade (SLOT). Laut Indonesia memiliki fungsi yang sangat penting bagi NKRI yaitu, laut sebagai media pemersatu bangsa, laut sebagai media perhubungan, laut sebagai media sumber daya, laut sebagai media pertahanan dan keamanan, serta laut sebagai media diplomasi [1]. NKRI memiliki 12 (dua belas) lembaga penegak hukum di laut, dari dua belas tersebut ada 6 (enam) lembaga yang memiliki kapal patroli sebagai alat penegakan hukum di laut dengan cara melaksanakan patroli di laut, yaitu : TNI Angkatan Laut, POLRI, Kementrian Pertahanan, Kementrian Kelautan dan Perikanan, Kementrian Perhubungan dan Bea Cukai. Selanjutnya ada 6 (enam) lembaga penegak hukum laut lainnya yang tidak memiliki kapal patroli, yaitu: kementrian Luar Negeri dan Dalam Negeri, kementrian Hukum dan HAM, Kementrian Keuangan, Kejaksaan Agung dan Badan Intelijen Negara [3], [4]. Selama ini dua belas lembaga tersebut telah menjalankan tugas dan fungsinya, tetapi belum dapat berjalan dengan optimal. Hal ini menunjukkan bahwa penegakan hukum, keamanan dan keselamatan di laut yang dilaksanakan oleh satuan-satuan patroli dari berbagai instansi belum mampu optimal karena masing-masing instansi mempunyai kebijakan, sarana-prasarana, SDM yang berbeda-beda, tidak dalam satu sistem yang terintegrasi, serta tidak dalam kesatuan komando dan kendali. Sehingga dapat dimengerti jika dalam pelaksanaan sering terjadi overlapping kewenangan dan friksi antara instansi bahkan ego sektoral diantara instansi tersebut [5], [6].

Permasalahan yang muncul untuk menganalisa tingkat kepentingan pada masing-masing kriteria dan alternatif adalah ketidakpastian dan kurang konsisten pengambil keputusan. Permasalahan tersebut bisa diselesaikan dengan mengkombinasi metode pengambil keputusan multi kriteria dan sistem cerdas yaitu Fuzzy AHP dan Fuzzy TOPSIS[7], [8]. Teknik Pengambilan keputusan multi kriteria berguna untuk mencari pilihan yang terbaik dari semua pilihan alternatif dengan beberapa kriteria yang biasanya satu dan lainnya bertentangan [9], [10], [11]. Beberapa penelitian tentang konsep pengamanan laut Indonesia telah banyak dilakukan oleh beberapa peneliti, yaitu : kebijakan keamanan maritim yang terintegrasi mengharuskan adanya pertimbangan banyak aktor dalam pembuatan keputusan, dua aktor besar yaitu berasal dari sektor Negara dan sektor sipil [2]. Keamanan untuk wilayah pulau-pulau terluar dapat ditingkatkan dengan model penguatan kelembagaan Pemerintah antara pusat dan daerah, ditunjang dengan peningkatan sumber daya manusia dan peningkatan kesejahteraan masyarakat dengan memanfaatkan potensi pulau-pulau terluar [12]. Konsep poros maritim dunia adalah konsep keamanan maritim itu sendiri dengan karakteristik yang menonjol dan berfokus pada empat aspek yaitu keamanan nasional, keamanan ekonomi, keamanan lingkungan dan keamanan manusia [13].

Faktor yang menyebabkan lemahnya penegakan hukum perikanan di laut Indonesia diantaranya adalah faktor egosektoral instansi penegak hukum perikanan yang dilakukan oleh PPNS Perikanan, Polisi, TNI AL dan Bakamla [14], [15]. Secara garis besar, kendala pemenuhan infrastruktur yang memadai dalam kemaritiman merupakan kendala utama yang harus diselesaikan Pemerintah. Karena keberadaan infrastruktur akan mempengaruhi kualitas pengawasan dan pengamanan laut Indonesia [6], [15], [16]. 
Keberadaan Bakamla tidak menghapus kewenangan instansi lain, namun terkandung potensi konflik kepentingan antar instansi penegak hukum dilaut yang perlu diantisipasi dan diwaspadai, sebagai rekomendasi kepada pemerintah agar lebih serius dalam mensinergikan penegakan hukum di laut sehingga benturan antar aparat penegak hukum dilaut dapat dihindari [17]. Peran dan upaya Bakamla menyelamatkan Sumber Daya Alam Indonesia sektor kelautan [18], konsep doktrin maritim dan strategi militer khususnya TNI AL sebagai instrumen kekuatan keamanan laut Indonesia [19], [20], [21].

\section{Dasar Teori}

\subsection{Fuzzzy AHP}

Fuzzy Analytic Hierarcy Process (F-AHP) adalah salah satu metode perankingan. F-AHP merupakan gabungan metode AHP dengan pendekatan konsep fuzzy. F-AHP menutupi kelemahan yang terdapat pada AHP, yaitu permasalahan terhadap kriteria yang memiliki sifat subjektif lebih banyak. Ketidakpastian bilangan direpresentasikan dengan urutan skala. Untuk menentukan derajat keanggotaan pada F-AHP digunakan aturan fungsi dalam bentuk bilangan fuzzy segitiga atau Triangular Fuzzy Number (TFN) yang disusun berdasarkan himpunan linguistik. Jadi, bilangan pada tingkat intensitas kepentingan pada AHP ditransformasikan ke dalam himpunan skala TFN. Ada beberapa cara yang dapat dilakukan dalam menyelesaikan permasalahan pembobotan F-AHP. Pada teori F-AHP yang dikembangkan oleh [22] telah banyak diterapkan dalam penyelesaian beberapa studi kasus.

Menurut [22] dalam sebuah publikasinya, untuk menyelesaikan permasalahan multi kriteria dengan F-AHP ada beberapa tahapan yang harus dilakukan sebagai berikut:

1. Membuat struktur hirarki masalah yang akan diselesaikan dan menentukan perbandingan matriks berpasangan antar kriteria dengan skala TFN.

2. Menentukan nilai sintesis fuzzy $\left(\mathrm{S}_{\mathrm{i}}\right)$ prioritas dengan rumus $\left(\mathrm{S}_{\mathrm{i}}\right)$.

3. Jika hasil yang diperoleh pada setiap matrik fuzzy, $\mathbf{M}_{2}=\left(\mathrm{l}_{2}, \mathrm{~m}_{2}, \mathrm{u}_{2}\right) \geq \mathrm{M}_{1}=\left(\mathrm{l}_{1}, \mathrm{~m}_{1}\right.$, $\mathrm{u}_{1}$ ) dapat didefinisikan sebagai nilai vektor.

4. Jika hasil nilai fuzzy lebih besar dari $\mathrm{k} f u z z y, \mathrm{M}_{\mathrm{i}}(\mathrm{i}=, 1,2, \ldots, \mathrm{k})$ yang dapat difenisikan sebagai nilai ordinat

5. Normalisasi bobot vektor atau nilai prioritas kriteria yang telah diperoleh, $\mathrm{W}=(\mathrm{d}(\mathrm{A} 1), \mathrm{d}(\mathrm{A} 2), \ldots, \mathrm{d}(\mathrm{An})$ Dimana $\mathrm{W}$ adalah bilangan non- fuzzy.

\subsection{Fuzzy TOPSIS}

Metode TOPSIS (Technique for Order Preference by Similarity to Ideal Solution) didasarkan pada konsep, dimana alternatif terpilih yang baik tidak hanya memiliki jarak terpendek dari solusi ideal positif yaitu memaksimalkan kriteria manfaat dan meminimalkan kriteria biaya, namun juga memiliki jarak terpanjang dari solusi ideal negatif yaitu memaksimalkan kriteria biaya dan meminimalkan kriteria manfaat. Untuk menyelesaikan permasalahan multi kriteria dengan metode TOPSIS ada beberapa tahapan yang harus diselesaikan, yaitu :

1. Membuat matriks keputusan yang ternormalisasi.

2. Membuat matriks keputusan yang ternormalisasi terbobot.

3. Menentukan matriks solusi ideal positif dan matriks solusi ideal negatif.

4. Menentukan jarak antara nilai setiap alternatif dengan matriks solusi ideal positif dan matriks solusi ideal negatif.

5. Menentukan nilai preferensi untuk setiap alternatif. 


\section{Perangkingan.}

\section{Metodologi Penelitian}

Penelitian ini dimulai dengan menentukan kriteria yang menjadi pertimbangan pemilihan model keamanan laut yang cocok untuk Indonesia seperti Tabel 1. Setelah kriteria disepakati, selanjutnya menentukan alternatif (model pengamanan laut) yang akan dinilai.

Tabel 1. Kriteria keputusan

\begin{tabular}{cl}
\hline Kode & \multicolumn{1}{c}{ Kriteria } \\
\hline C1 & Politik \\
C2 & Ekonomi \\
C3 & Sosial dan Budaya \\
C4 & Teknologi \\
C5 & Infrastruktur \\
C6 & Kebijakan \\
\hline
\end{tabular}

Tabel 2. Alternatif keputusan

\begin{tabular}{cl}
\hline Kode & \multicolumn{1}{c}{ Alternatif } \\
\hline A1 & Multy Agency Single Task \\
A2 & Multy Agency Multy Task \\
A3 & Single Agency Multy Task \\
A4 & Single Agency Single Task \\
\hline
\end{tabular}

Untuk memperoleh data tingkat kepentingan pada masing-masing kriteria dan aternatif, maka peneliti menyebarkan kuisioner kepada 100 responden. Responden yang diambil dalam penelitian ini adalah: TNI AL, kementrian Kelautan dan Perikanan, kementrian Perhubungan, kementrian Pertahanan dan Akademisi.

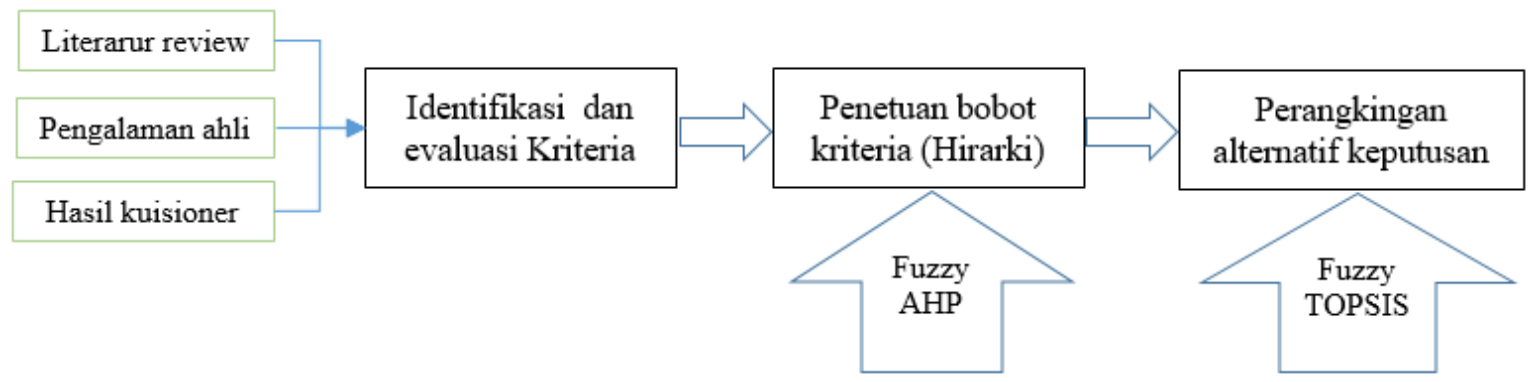

Gambar 1. Tahapan prosedur evaluasi (Fuzzy AHP dan Fuzzy TOPSIS)

Gambar 1 menjelaskan tentang tahapan proses penilaian model keamanan laut yang paling cocok untuk Indonesia ditinjau dari kriteria yang telah ditetapkan. Metode Fuzzy AHP digunakan untuk menilai tingkat kepentingan pada masing-masing kriteria, setelah nilai rating kriteria diperoleh akan dijadikan acuan sebagai bobot pada metode Fuzzy TOPSIS sehingga akan diperoleh hasil akhir rangking keputusan terbaik.

\section{Pengujian dan Pembahasan}

Hasil penyebaran kuisioner kepada 100 responden dengan pendekatan tingkat kepentingan menurut Thomas L. Saaty dapat dilihat pada Tabel.3.

Tabel 3. Nilai rekap 100 kuisioner dengan model AHP

\begin{tabular}{ccccccc}
\hline Kriteria & $\mathbf{C 1}$ & $\mathbf{C 2}$ & $\mathbf{C 3}$ & $\mathbf{C 4}$ & $\mathbf{C 5}$ & $\mathbf{C 6}$ \\
\hline C1 & 1,000 & 0,333 & 5,000 & 0,143 & 0,333 & 0,200 \\
C2 & 3,000 & 1,000 & 5,000 & 0,200 & 1,000 & 0,333 \\
C3 & 0,200 & 0,200 & 1,000 & 0,143 & 0,200 & 0,143 \\
C4 & 7,000 & 5,000 & 7,000 & 1,000 & 5,000 & 3,000 \\
C5 & 3,000 & 1,000 & 5,000 & 0,200 & 1,000 & 0,333 \\
C6 & 5,000 & 3,000 & 7,000 & 0,333 & 3,000 & 1,000 \\
\hline
\end{tabular}

Selanjutnya dibuat model matrik keputusan fuzzy AHP. Nilai dari model fuzzy AHP yang diperoleh dari kuisioner untuk membandingkan masing-masing kriteria. Nilai hasil kuisioner 
tersebut dibandingkan dengan mengacu pada penilaian intensitas kepentingan AHP, dan diperoleh hasil matrik keputusan Fuzzy AHP seperti Tabel 4.

Tabel 4. Matrik keputusan fuzzy AHP

\begin{tabular}{|c|c|c|c|c|c|c|c|c|c|c|c|c|c|c|c|c|c|c|}
\hline \multirow{2}{*}{ Kriteria- } & \multicolumn{3}{|c|}{ C1 } & \multicolumn{3}{|c|}{$\mathrm{C2}$} & \multicolumn{3}{|c|}{$\mathrm{C3}$} & \multicolumn{3}{|c|}{$\mathrm{C} 4$} & \multicolumn{3}{|c|}{ C5 } & \multicolumn{3}{|c|}{ C6 } \\
\hline & $\mathrm{L}$ & M & $\mathrm{U}$ & $\mathrm{L}$ & M & $\mathrm{U}$ & $\mathrm{L}$ & M & $\mathrm{U}$ & $\mathrm{L}$ & M & $\mathrm{U}$ & $\mathrm{L}$ & M & $\mathrm{U}$ & $\mathrm{L}$ & M & $\mathrm{U}$ \\
\hline $\mathrm{C1}$ & 1,00 & 1,00 & 3,00 & 1,00 & 0,33 & 0,20 & 3,00 & 5,00 & 7,00 & 0,20 & 0,14 & 0,11 & 1,00 & 0,33 & 0,20 & 0,33 & 0,20 & 0,14 \\
\hline $\mathrm{C} 2$ & 1,00 & 3,00 & 5,00 & 1,00 & 1,00 & 3,00 & 3,00 & 5,00 & 7,00 & 0,33 & 0,20 & 0,14 & 1,00 & 1,00 & 3,00 & 1,00 & 0,33 & 0,20 \\
\hline $\mathrm{C3}$ & 0,33 & 0,20 & 0,14 & 0,33 & 0,20 & 0,14 & 1,00 & 1,00 & 3,00 & 0,20 & 0,14 & 0,11 & 0,33 & 0,20 & 0,14 & 0,20 & 0,14 & 0,11 \\
\hline $\mathrm{C4}$ & 5,00 & 7,00 & 9,00 & 3,00 & 5,00 & 7,00 & 5,00 & 7,00 & 9,00 & 1,00 & 1,00 & 3,00 & 5,00 & 7,00 & 9,00 & 1,00 & 3,00 & 5,00 \\
\hline C5 & 1,00 & 3,00 & 5,00 & 1,00 & 1,00 & 0,33 & 3,00 & 5,00 & 7,00 & 0,20 & 0,14 & 0,11 & 1,00 & 1,00 & 3,00 & 1,00 & 0,33 & 0,20 \\
\hline C6 & 3,00 & 5,00 & 7,00 & 1,00 & 3,00 & 5,00 & 5,00 & 7,00 & 9,00 & 1,00 & 0,33 & 0,20 & 1,00 & 3,00 & 5,00 & 1,00 & 1,00 & 3,00 \\
\hline
\end{tabular}

Berdasarkan Tabel 4, proses untuk mendapatkan nilai jumlah baris dan kolom menggunakan persamaan (7) dan (8), hasilnya dapat dilihat pada Tabel 5. Kemudian elemen-elemen matrik perbandingan pada Tabel. 4 dibagi dengan nilai pada baris jumlah. Setelah itu mencari vector eigen atau bobot masing-masing kriteria dengan cara menjumlahkan nilai-nilai dalam setiap baris, kemudian dibagi dengan banyaknya kriteria.

Tabel 5. Hasil perhitungan jumlah baris, kolom dan nilai invers

\begin{tabular}{cccc}
\hline \multirow{2}{*}{ Kriteria } & \multicolumn{3}{c}{ Nilai jumlah baris } \\
& $\mathrm{L}$ & $\mathrm{M}$ & $\mathrm{U}$ \\
\hline $\mathbf{C 1}$ & 6,53 & 7,01 & 10,65 \\
$\mathbf{C 2}$ & 7,33 & 10,53 & 18,34 \\
$\mathbf{C 3}$ & 2,40 & 1,89 & 3,65 \\
$\mathbf{C 4}$ & 20,00 & 30,00 & 42,00 \\
$\mathbf{C 5}$ & 7,20 & 10,48 & 15,64 \\
$\mathbf{C 6}$ & 12,00 & 19,33 & 29,20 \\
\hline
\end{tabular}

\begin{tabular}{ccccccc}
\hline \multicolumn{3}{c}{ Nilai Jumlah Kolom } & & \multicolumn{4}{c}{ Nilai invers } \\
L & M & U & & L & M & U \\
\hline 55,47 & 79,24 & 119,49 \\
\cline { 5 - 7 }
\end{tabular}$\quad$\begin{tabular}{ccc}
0,01 & 0,01 & 0,02 \\
\hline
\end{tabular}

Selanjutnya adalah proses penentuan nilai vektor (V) dan nilai ordinat defuzzifikasi. Proses ini menggunakan pendekatan fuzzy yaitu fungsi implikasi minimum (min) fuzzy. Setelah dilakukan perbandingan nilai sintesis fuzzy, akan diperoleh nilai ordinat defuzzifikasi (d') yaitu nilai d' minimum. Berdasarkan persamaan (1) dan (2), maka diperoleh nilai vector dan nilai ordinat defuzzifikasi dari masing-masing kriteria.

Kriteria 1 adalah Politik $\left(\mathrm{K}_{1}\right)$, nilai vectornya adalah :

$$
\left(\mathrm{VK}_{1}\right) \geq\left(\mathrm{VK}_{2}, \mathrm{VK}_{3}, \mathrm{VK}_{4}, \mathrm{VK}_{5}, \mathrm{VK}_{6}\right)
$$

Karena nilai $\mathrm{m} 1 \geq \mathrm{m} 2$ dan $\mathrm{u} 2 \geq 11$ maka digunakan nilai $\mathrm{VK}_{1} \geq \mathrm{VK}_{2}$ :

$$
\begin{aligned}
\mathrm{VK}_{1} \geq \mathrm{VK}_{2} & =0.86 \\
\mathrm{VK}_{1} \geq \mathrm{VK}_{3} & =1 \\
\mathrm{VK}_{1} \geq \mathrm{VK}_{4} & =0.67 \\
\mathrm{VK}_{1} \geq \mathrm{VK}_{5} & =0.83 \\
\mathrm{VK}_{1} \geq \mathrm{VK}_{6} & =0.73
\end{aligned}
$$

Sehingga diperoleh nilai d' $\left(\mathrm{VK}_{1}\right)$ adalah:

$$
\begin{aligned}
& \mathrm{d}^{\prime}\left(\mathrm{VK}_{1}\right)=\min (0.86,1,0.67,0.83,0.73) \\
& \mathrm{d}^{\prime}\left(\mathrm{VK}_{1}\right)=0.67
\end{aligned}
$$

Maka dengan cara yang sama untuk menghitung kriteria 1,3,4,5 dan 6, yaitu:

- Kriteria 2 adalah Ekonomi $\left(\mathrm{K}_{2}\right)$, diperoleh nilai vektor $=\mathrm{d}^{\prime}\left(\mathrm{VK}_{2}\right)=0.71$

- Kriteria 3 adalah Sosial-budaya $\left(\mathrm{K}_{3}\right)$, diperoleh nilai vektor $=\mathrm{d}^{\prime}\left(\mathrm{VK}_{3}\right)=0.62$

- Kriteria 4 adalah Teknologi $\left(\mathrm{K}_{4}\right)$, diperoleh nilai vektor $=\mathrm{d}^{\prime}\left(\mathrm{VK}_{4}\right)=1$

- Kriteria 5 adalah Infrastruktur $\left(\mathrm{K}_{5}\right)$, diperoleh nilai vektor $=\mathrm{d}^{\prime}\left(\mathrm{VK}_{5}\right)=0.71$ 
- Kriteria 6 adalah Regulasi $\left(\mathrm{K}_{6}\right)$, diperoleh nilai vektor $=\mathrm{d}^{\prime}\left(\mathrm{VK}_{6}\right)=0.81$

Total nilai bobot vektor pada masing-masing kriteria dijumlahkan $\mathrm{W}=\left(\mathrm{VK}_{1}+\mathrm{VK}_{2}+\mathrm{VK}_{3}+\right.$ $\left.\mathrm{VK}_{4}+\mathrm{VK}_{5}+\mathrm{VK}_{6}\right)$. Sehingga nilai total bobot vektor kriteria diperoleh $\mathrm{W}=(0.19+0.20+0.18$ $+0.28+0.20+0.23)=1.28$. Normalisasi nilai bobot vektor sebagai berikut :

$$
\begin{aligned}
\mathrm{WK}_{1} & =0.19 / 1.28=0.15 \\
\mathrm{WK}_{2} & =0.20 / 1.28=0.16 \\
\mathrm{WK}_{3} & =0.18 / 1.28=0.14 \\
\mathrm{WK}_{4} & =0.28 / 1.28=0.22 \\
\mathrm{WK}_{5} & =0.20 / 1.28=0.16 \\
\mathrm{WK}_{6} & =0.23 / 1.28=0.18
\end{aligned}
$$

Berdasarkan hasil analisa tingkat kepentingan kriteria menggunakan metode Fuzzy AHP, ternyata kriteria yang sangat berpengaruh terhadap peningkatan kualitas keamanan laut Indonesia adalah teknologi, regulasi, infrastruktur, ekonomi, politik dan sosial budaya. Hasil analisa tingkat kepentingan kriteria yang mempengaruhi kualitas pengamanan laut dapat dilihat pada Gambar 2.

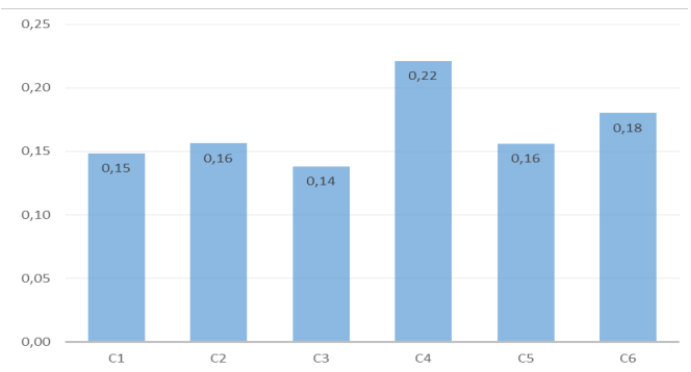

Gambar 2. Hasil rangking kriteria menggunakan Fuzzy AHP

Selanjutnya, setelah diperoleh nilai bobot kriteria maka berikutnya melanjutkan perhitungan dengan fuzzy TOPSIS yaitu mencari nilai kuadrat dan akar hasil penilaian dengan kuisioner. Tabel 6 adalah nilai rating di kuisioner dan nilai konversi ke dalam fuzzy.

Tabel 6. Rating nilai kuisioner

\begin{tabular}{lcc}
\hline \multicolumn{1}{c}{ Variabel } & Kode & TFN \\
\hline Sangat Jelek & SJ & $(1,1,1)$ \\
Jelek & J & $(1,3,5)$ \\
Cukup & C & $(3,5,7)$ \\
Baik & B & $(5,7,9)$ \\
Sangat Baik & SB & $(7,9,9)$ \\
\hline
\end{tabular}

Tabel 7. Hasil rekap kuisioner

\begin{tabular}{ccccccc}
\hline Alternative & C1 & C2 & C3 & C4 & C5 & C6 \\
\hline A1 & B & C & B & B & B & B \\
A2 & C & P & C & J & B & J \\
A3 & SB & B & B & SB & B & SB \\
A4 & J & SB & C & B & B & C \\
\hline
\end{tabular}

\begin{tabular}{|c|c|c|c|c|c|c|c|c|c|c|c|c|c|c|c|c|c|c|}
\hline \multirow{2}{*}{ Alternatif } & \multicolumn{3}{|c|}{$\mathrm{C} 1$} & \multicolumn{3}{|c|}{$\mathrm{C} 2$} & \multicolumn{3}{|c|}{$\mathrm{C3}$} & \multicolumn{3}{|c|}{$\mathrm{C4}$} & \multicolumn{3}{|c|}{ C5 } & \multicolumn{3}{|c|}{ C6 } \\
\hline & $\mathrm{L}$ & $\mathrm{M}$ & $\mathrm{U}$ & $\mathrm{L}$ & $\mathrm{M}$ & $\mathrm{U}$ & $\mathrm{L}$ & M & $\mathrm{U}$ & $\mathrm{L}$ & M & $\mathrm{U}$ & $\mathrm{L}$ & M & $\mathrm{U}$ & $\mathrm{L}$ & M & $\mathrm{U}$ \\
\hline A1 & 5,00 & 7,00 & 9,00 & 3,00 & 5,00 & 7,00 & 5,00 & 7,00 & 9,00 & 5,00 & 7,00 & 9,00 & 5,00 & 7,00 & 9,00 & 5,00 & 7,00 & 9,00 \\
\hline A2 & 3,00 & 5,00 & 7,00 & 1,00 & 3,00 & 5,00 & 3,00 & 5,00 & 7,00 & 1,00 & 3,00 & 5,00 & 5,00 & 7,00 & 9,00 & 1,00 & 3,00 & 5,00 \\
\hline A3 & 7,00 & 9,00 & 9,00 & 5,00 & 7,00 & 9,00 & 5,00 & 7,00 & 9,00 & 7,00 & 9,00 & 9,00 & 5,00 & 7,00 & 9,00 & 7,00 & 9,00 & 9,00 \\
\hline A4 & 1,00 & 3,00 & 5,00 & 7,00 & 9,00 & 9,00 & 3,00 & 5,00 & 7,00 & 5,00 & 7,00 & 9,00 & 5,00 & 7,00 & 9,00 & 3,00 & 5,00 & 7,00 \\
\hline
\end{tabular}

Tabel.7 adalah hasil rekapitulasi kuisioner penilaian model keamanan laut di Indonesia dengan mengacu pada rating nilai yang telah ditetapkan. Setelah diperoleh rekap nilai kuisioner, selanjutnya melakukan konversi proses penilaian kedalam bentuk fuzzy, hasil konversi nilai kuisioner kedalam bentuk fuzzy dapat dilihat pada Tabel 8 .

Tabel 8. Nilai rekap 100 kuisioner dengan model fuzzy 
Setelah diperoleh matriks keputusan dengan model fuzzy, maka selanjutnya menghitung nilai rata-rata pada nilai kriteria terhadap alternatif keputusan menjadi satu nilai saja. Hasil perhitungan rata-rata keputusan tersebut dapat dilihat pada Tabel 9. Selanjutnya setelah diperoleh nilai perbandingan kriteria dan alternatif, maka langkah berikutnya melanjutkan perhitungan Fuzzy TOPSIS yaitu mencari nilai kuadrat dan akar hasil penilaian pada Tabel. 10.

Tabel 9. Hasil rekapitulasi nilai kepentingan

Tabel 10. Nilai kuadrat dan akar hasil kuisioner

\begin{tabular}{cccccccccccccccc}
\hline Alternatif & C1 & $\mathbf{C 2}$ & $\mathbf{C 3}$ & $\mathbf{C 4}$ & $\mathbf{C 5}$ & $\mathbf{C 6}$ & & & Kriteria & C1 & C2 & C3 & C4 & C5 & C6 \\
\hline A1 & 7,00 & 5,00 & 7,00 & 7,00 & 7,00 & 7,00 & & Kuadrat & 152,44 & 152,44 & 148,00 & 176,44 & 196,00 & 152,44 \\
A2 & 5,00 & 3,00 & 5,00 & 3,00 & 7,00 & 3,00 & & Akar & 12,35 & 12,35 & 12,17 & 13,28 & 14,00 & 12,35 \\
A3 & 8,33 & 7,00 & 7,00 & 8,33 & 7,00 & 8,33 & & & & & & & \\
A4 & 3,00 & 8,33 & 5,00 & 7,00 & 7,00 & 5,00 \\
Average & $\mathbf{5 , 8 3}$ & $\mathbf{5 , 8 3}$ & $\mathbf{6 , 0 0}$ & $\mathbf{6 , 3 3}$ & $\mathbf{7 , 0 0}$ & $\mathbf{5 , 8 3}$ & & & & & & & \\
\hline
\end{tabular}

Setelah diperoleh nilai akar pada matriks keputusan Tabel.11, maka selanjutnya mencari matrik normalisasi dengan cara mengalikan setiap nilai matriks dengan nilai akar kriteria, sehingga diperoleh hasil nilai matrik normalisasi seperti Tabel 12.

Tabel 11. Matrik normalisasi

\begin{tabular}{ccccccc}
\hline Alternatif & C1 & C2 & C3 & C4 & C5 & C6 \\
\hline A1 & 0,567 & 0,405 & 0,575 & 0,527 & 0,500 & 0,567 \\
A2 & 0,405 & 0,243 & 0,411 & 0,226 & 0,500 & 0,243 \\
A3 & 0,675 & 0,567 & 0,575 & 0,627 & 0,500 & 0,675 \\
A4 & 0,243 & 0,675 & 0,411 & 0,527 & 0,500 & 0,405 \\
\hline
\end{tabular}

Tabel 12. Matrik normalisasi terbobot

\begin{tabular}{ccccccc}
\hline Alternatif & C1 & C2 & C3 & C4 & C5 & C6 \\
\hline A1 & 0,084 & 0,063 & 0,079 & 0,073 & 0,078 & 0,102 \\
A2 & 0,060 & 0,038 & 0,057 & 0,031 & 0,078 & 0,044 \\
A3 & 0,100 & 0,089 & 0,079 & 0,087 & 0,078 & 0,122 \\
A4 & 0,036 & 0,105 & 0,057 & 0,073 & 0,078 & 0,073 \\
\hline
\end{tabular}

Setelah diperoleh nilai normalisasi matrik terbobot Fuzzy TOPSIS dan Fuzzy AHP, maka selanjutnya mencari nilai solusi positif dan solusi negatif, dengan mencari nilai maksimum dan minimum. Untuk mencari jarak antar alternatif dengan matriks solusi ideal positif dapat menggunakan persamaan sebagai berikut:

$$
D_{i}^{+}=\sqrt{\sum_{j=1}^{n}\left(y_{i}^{+}-y_{i j}\right)^{2}} \quad D_{i}^{-}=\sqrt{\sum_{j=1}^{n}\left(y_{i j}-y_{i}^{-}\right)^{2}} \quad \mathrm{i}=1,2, . ., \mathrm{m}
$$

Hasil dari jarak solusi ideal positif dan negatif dapat dilihat pada Tabel 13. Selanjutnya adalah menentukan nilai kuadrat dan akar dari nilai ideal positif dan nilai ideal negatif. Hasil dari nilai kuadrat dapat dilihat pada Tabel 13 dan nilai akar dapat dilihat pada Tabel 14.

Tabel 13. Nilai jarak terhadap solusi ideal positif dan negatif

\begin{tabular}{ccccccc}
\hline Nilai & C1 & C2 & C3 & C4 & C5 & C6 \\
\hline Maksimum & 0,100 & 0,105 & 0,079 & 0,087 & 0,078 & 0,122 \\
Minimum & 0,036 & 0,038 & 0,057 & 0,031 & 0,078 & 0,044 \\
\hline
\end{tabular}

Tabel 14. Nilai kuadrat pada alternatif

\begin{tabular}{ccc}
\hline Nilai Kuadrat & Benefit & Cost \\
\hline A1 & 0,003 & 0,009 \\
A2 & 0,016 & 0,001 \\
A3 & 0,000 & 0,016 \\
A4 & 0,007 & 0,007 \\
\hline
\end{tabular}

Setelah memperoleh nilai kuadrat dan akar dari nilai ideal positif dan negatif. Maka langkah terakhir dalam perhitungan Fuzzy TOPSIS adalah mencari nilai preferensi untuk setiap alternatif diberikan sesuai dengan persamaan berikut :

$$
V_{i}=\frac{D_{i}^{-}}{D_{i}^{-}+D_{i}^{+}}
$$


Setelah diperoleh nilai prioritas pada masing-masing alternatif, selanjutnya dilakukan proses normalisasi terhadap nilai keputusan tersebut, sehingga diperoleh nilai seperti terlihat pada Tabel 15.

Tabel 15. Nilai akar pada alternatif

\begin{tabular}{ccc}
\hline Nilai Akar & Benefit & Cost \\
\hline A1 & 0,051 & 0,093 \\
A2 & 0,126 & 0,024 \\
A3 & 0,017 & 0,128 \\
A4 & 0,085 & 0,084 \\
\hline
\end{tabular}

Tabel 16. Nilai prioritas alternatif pemilihan konsep pengamanan laut Indonesia

\begin{tabular}{ccc}
\hline Alternatif & $\begin{array}{c}\text { Nilai } \\
\text { Prioritas }\end{array}$ & $\begin{array}{c}\text { Nilai } \\
\text { Prioritas }\end{array}$ \\
\hline A1 & 0,645 & 0,295 \\
A2 & 0,160 & 0,073 \\
A3 & 0,883 & 0,404 \\
A4 & 0,499 & 0,228 \\
\hline & $\mathbf{2 , 1 8 8}$ & $\mathbf{1 , 0 0 0}$ \\
\hline
\end{tabular}

Berdasarkan analisa kepentingan terhadap beberapa konsep pengamanan laut, ternyata konsep yang paling cocok untuk diimplementasikan di Negara Indonesia adalah konsep Single Agency Multy Task, dimana segala kebijakan dalam penanganan penegakan hukum di laut berada dalam naungan satu lembaga.

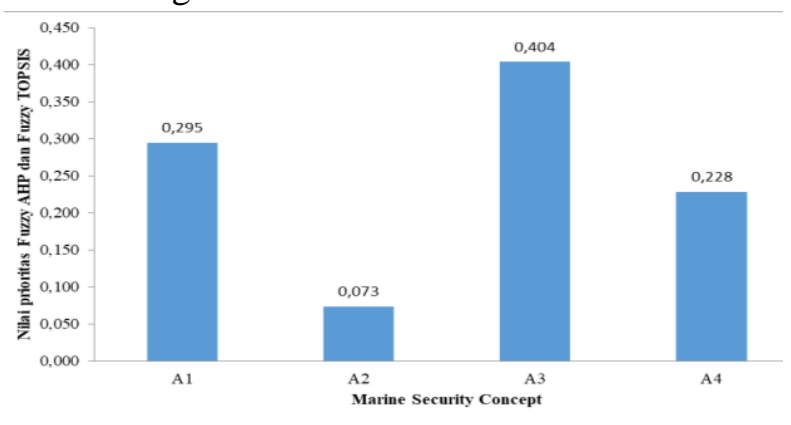

Gambar 3. Hasil prioritas model pengamanan laut Indonesia

Gambar 3 memberikan penjelasan bahwa konsep "Single Agency Multy Tasks" diyakini dapat memberikan kontribusi besar dalam mengatasi berbagai persoalan dalam penegakan hukum keamanan dan keselamatan di laut Indonesia, hal ini mengingat karakteristik sistem "Single Agency Multy Tasks" yang sangat berbeda dengan sistem yang lain. Dalam konteks keIndonesiaan penerapan sistem "Single Agency Multy Tasks" dapat dilakukan dengan jalan mengoptimalkan segenap kewenangan, kekuatan dan kemampuan yang dimiliki stakeholder secara sinergi dengan tidak menghapus stakeholder yang ada dan fungsi/kewenangan utamanya serta peraturan perundang-undangan yang memberikan kewenangan kepadanya.

\section{Kesimpulan}

Penerapan metode Fuzzy AHP dan Fuzzy TOPSIS dalam pemilihan model keamanan laut di Indonesia dapat memberikan rekomendasi alternatif untuk pengambil keputusan, sehingga proses pemilihan konsep bisa berjalan secara efektif dan efisien serta menghasilkan keputusan yang konsisten. 
Hasil perhitungan bobot kriteria menggunakan metode Fuzzy AHP diperoleh bobot nilai sebagai berikut: [1] Teknologi $=0.22$, [2] Regulasi $=0.18$, [3] Infrastruktur dan ekonomi $=0.16$, [4] Politik $=0.15$ dan [5] Politik $=0.14$. Hasil perhitungan metode Fuzzy TOPSIS diperoleh prioritas alternatif keputusan sebagai berikut: [1] Single Agency Multy Task $=0.404$, [2] Multy Agency Single Task $=0.295$, [3] Single Agency Single Task $=0.228$ dan [4] Multy Agency Multy Task $=0.073$.

Hasil implementasi Multi Criteria Decision Making (MCDM) dengan metode Fuzzy AHP dan Fuzzy TOPSIS yang telah merekomendasikan konsep pengamanan laut Indonesia terbaik adalah Single Agency Multy Task, konsep tersebut diyakini dapat memberikan kontribusi besar dalam mengatasi berbagai persoalan dalam penegakan hukum keamanan dan keselamatan di laut, konsep tersebut menghendaki adanya satu lembaga atau badan bersifat tunggal, integratif dan dalam pelaksanaan operasinya ada pada "satu komando", sehingga cita-cita bangsa untuk menjadikan Indonesia sebagai poros maritim dunia bisa terwujud.

\section{Ucapan Terima Kasih}

Kepada Kemenristekdikti Republik Indonesia yang telah membiayai penelitian ini melalui skim penelitian Strategis Nasional pada tahun anggaran 2018

\section{Daftar Pustaka}

[1] A. Kadar, "Pengelolaan kemaritiman menuju Indonesia sebagai poros maritim dunia," $J$. Keamanan Nas., Vol. VI, No. 21, pp. 427-442, 2014.

[2] M. Keliat, "Keamanan maritim dan implikasi kebijakan bagi Indonesia," J. Ilmu Sos. dan Ilmu Polit., Vol. 13, No. 1, pp. 111-129, 2009.

[3] R. Samiaji and S. Satkor, "Harmonisasi kewenangan lembaga negara dalam menanggulangi tindak pidana Illegal Fishing di perairan Indonesia," 2014.

[4] E. M. Wulansari, "Penegakan hukum di laut dengan sistem single agency multy task," Media Pembinaan Hukum Nasional, pp. 1-6, 2014.

[5] L. B. Buzan and O. Waever, "Konsep dan strategi pertahanan Negara di laut dalam menghadapi ancaman militer sebagai bagian dari fungsi pangkalan," 2013.

[6] G. Gugustomo, "Badan Keamanan Laut sebagai single agency multy task dalam bidang keamanan wilayah laut Indonesia," 2014.

[7] H. Heru Lumaksono, "Sistem Pendukung Keputusan untuk Menentukan Alat Tangkap yang Sesuai bagi Nelayan di Madura," in Seminar MASTER 2017 PPNS, 2017, vol. 1509, pp. 1-6.

[8] Y. K. Hozairi, "Decision Support System Determination of Main Work Unit in WPP-711 using Fuzzy TOPSIS,” Knowl. Eng. Data Sci., vol. 1, no. 1, pp. 8-19, 2018.

[9] F. Rodrigues, L. Junior, L. Osiro, L. Cesar, and R. Carpinetti, "A comparison between Fuzzy AHP and Fuzzy TOPSIS methods to supplier selection," Appl. Soft Comput. J., vol. 21, pp. 194-209, 2014.

[10] S. H. Zyoud, L. G. Kaufmann, H. Shaheen, S. Samhan, and D. Fuchs-hanusch, "A framework for water loss management in developing countries under fuzzy environment: Integration of Fuzzy AHP with Fuzzy TOPSIS," Expert Syst. Appl., vol. 61, pp. 86-105, 2016.

[11] R. K. Shukla, D. Garg, and A. Agarwal, "An integrated approach of Fuzzy AHP and Fuzzy TOPSIS in modeling supply chain coordination," Prod. Manuf. Res., vol. 2, no. 1, pp. 415-438, 2014. 
[12] A. Torry and S. Kusumo, "Optimasi pengelolaan dan pemberdayaan pulau-pulau terluar dalam rangka mempertahankan keutuhan NKRI," J. Din. Huk., vol. 1, no. 3, pp. 327$337,2010$.

[13] A. H. I Nengah Putra A, "Analisa peluang dan ancaman keamanan maritim Indonesia sebagai dampak perkembangan lingkungan strategis," 2012.

[14] R. W. Ikhtiari, "Strategi keamanan maritim Indonesia dalam menanggulangi ancaman non-traditional security," 2011.

[15] D. R. Munaf, "Studi analisis tipikal infrastruktur keamanan laut di pusat dan daerah," $J$. Sosioteknologi, vol. 1, no. April 2013, pp. 320-339, 2013.

[16] I. Jaya and M. Pd, Evaluation of Indonesian Marine Safety. 2014.

[17] G. Wasito, "Kewenangan BAKAMLA dalam penegakan hukum tindak pidana tertentu dilaut berdasarkan UU.No.32 Tahun 2014 tentang kelautan," 2015.

[18] D. A. Mamahit, "Peran dan upaya BAKAMLA dalam penyelamatan sumber daya alan Indonesia sektor kelautan," 2015.

[19] Salim, "Konsep doktrin maritim dan strategi militer maritim Indonesia," 2015.

[20] Bappenas, "Prakarsa strategis optimalisasi pemanfataan potensi kelautan menuju terwujudnya Indonesia sebagai poros maritim," 2016.

[21] L. J. Morris and G. P. Paoli, "A Preliminary Assessment of Indonesia ' s Maritime Security Threats and Capabilities," 2018.

[22] D.-Y. Chang, "Applications of the extent analysis method on fuzzy AHP," Eur. J. Oper. Res., Vol. 95, No. 3, pp. 649-655, 1996. 